\title{
Reasoning in Theory and Practice
}

\section{StePhen Toulmin University of Southern California}

\begin{abstract}
As my book The Uses of Argument pointed out, we must look and see how our critical standards vary from one area or activity to another-e.g. from politics to aesthetics. Hence we need to explore how these critical standards evolve, and how the most reflective and best-informed people in any area of experience refine those standards. We cannot understand where we are now unless we understand how we got here, even in a field like mathematics. Hence we must modestly recognize that the best we can do now is the best we can do now; and that those who come after us will move beyond our ideas. There is much contingency in these historical developments.
\end{abstract}

Résumé: Comme je l'indique dans mon livre, Uses of Argument, nous devons rechercher les critères d'évaluation et examiner comment ils varient d'un domaine à un autre (ex. de la politique à l'esthétique). Nous avons donc besoin de déterminer comment ces critères évoluent et se raffinent parmi les gens les plus réfléchis et les mieux informés dans n'importe quel domaine. Nous ne pouvons pas comprendre où nous sommes présentement à moins de comprendre comment nous y sommes arrivés, même dans une discipline telles que les mathématiques. Alors nous devons humblement reconnaître que nos meilleurs efforts sont présentement le mieux que nous puissions faire, et que ceux qui viendront après nous procèderont au-delà de nos idées. Ces développements historiques sont généralement contingents.

Keywords: argument, critical standards, The Uses of Argument, fields.

Let me begin with a word of gratitude to John Dewey. His book, Essays in Experimental Logic, was regarded with some contempt by my colleagues in Britain. But its great merit is to show, long before the rest of us, how reasoning enters not only into technical life, but also into everyday life; so that how we express ourselves and-more importantly - the activities within which we speak and act set the stage within which judgments of soundness and acceptability can alone be made.

That said, when I wrote The Uses of Argument, the last thing I intended to do was produce a theory of rhetoric. I wrote it as part of a polemical debate within British analytical philosophy around the year 1960 . Its first reception was entirely hostile. Peter Strawson dismissed it out of hand in The Listener; my colleague at Leeds, Peter Alexander called it "Toulmin's anti-logic book"; while Richard Braithwaite was deeply distressed by it, seeing me as abandoning the standards he had set up in the philosophy of science. One way or another, I concluded that, like David Hume's Treatise of Human Nature, my book would "fall still-born from the press." Yet it continued to sell for reasons that I understood only when I first came to the United States and found that it was being used up and down the 
Mississippi Valley as a theory of argumentation. This fact at first amazed me, but I am now perpetually grateful for it. The Uses of Argument is the only one of my books that has never gone out of print. Reason in Ethics was in print for thirtynine years, had a brief revival in paperback, but is now remaindered. The Uses of Argument continues to sell, and the royalties come in handy.

When my wife was taking her law courses at DePaul University in Chicago, the young man sitting next to her remarked her surname was familiar as his girlfriend was studying communication. My wife replied, "Oh, yes, I am married to him." Next week the young man came back and said, "No, my girlfriend said that was quite impossible. Toulmin lived shortly after Aristotle." I knew I was old, but not quite as old as that.

To come to the heart of the matter: when The Uses of Argument appeared, Otto Bird wrote about it as "a rediscovery of Aristotle's Topics." At the time, I did not understand this allusion, but more recently $\mathrm{l}$ have come to see he was right. Aristotle, as a man who was both a physician and the son of a physician, had a strong feeling for the practicality of reasoning and was in some ways a pioneer of medical ethics. In his Topics he introduces a useful distinction between "general" topics and "special" topics. General topics are things like metaphor, simile and analogy, which are equally at home with any subject matter and in any activity. Special topics have a bearing only within one activity rather than another: theoretical physics (say) rather than criminal law, politics rather than aesthetics, and so on. In each case, we must look and see how our critical standards vary from one area to another. We are all familiar with the legal distinction between proof beyond a reasonable doubt, clear and convincing evidence, and the like. These distinctions were crucial in the O.J. Simpson case: though somewhat bizarrely acquitted of the murder charge, he nevertheless was obliged to pay a lot of money to the dependants of those whom he was credibly believed to have killed.

So we need to explore further (as many of you have done) the ways in which standards of criticism evolve, and the manner in which the most reflective and best informed people in any area of experience refine those standards. As Imre Lakatos points out in his book, Proofs and Refutations, even the standards of mathematical rigor themselves have a history. What Theactetus regarded as rigorous would be quite insufficient to Gauss or Bourbaki. Our whole way of thinking about what considerations make mathematical arguments acceptable is itself a part of cultural history. This means that we cannot fully understand mathematics unless we see how our current formulations are the present stage in the history of mathematics. We cannot understand where we now are without understanding how we got here.

Once we understand this, the next step is to recognize that the work of successors will supersede our own ideas, so we must modestly recognize that the best we can now do is simply the best we can now do. Reflecting on when we live, where we live, and how we live, we can better see what our more reflective and experienced colleagues have come to understand, and what options are open to those who will come after us and move beyond our ideas. 
If it had not been the case that Albert Einstein had essentially visual imagination, twentieth century physical theory would not have developed as it did. From the late seventeenth century to the late nineteenth century-from Newton to Einsteinthe central ideas of mathematical physics were Cartesian, not just in the sense of demanding certainty, but in being, in a narrow sense, mechanical. Leibniz, of course, would not have regarded a computer as a machine: it has no cog wheels, and there is no mechanical engagement of forces. This was one of the reasons why Leibniz rejected Newton's theory of gravitation: there was no mechanical connection between the Sun and the Earth. We may have better ideas of how gravitation works, even though it remains one of the more mysterious features of the physical world. At any rate, we no long see it as purely mechanical: as a Yugoslav colleague of mine remarked, what we have here is the undermining of historical materialism by science, and a recognition that the world of ideas is in its own way as powerful as the world of mechanical forces and force-fields.

Henri Poincaré wrote a fine essay analyzing the foundations of Newtonian mechanics, which concluded that there are always liable to be critical interactions whose consequences are unpredictable, regardless of how small are the limitations of our demands. There are, as he puts it, always liable to be chocs: interactions whose consequences are intrinsically unpredictable. Indeed, if it had been possible to predict in advance exactly what the content of Beethoven's Choral Symphony was going to be, that would turn Beethoven himself into a plagiarist: he would merely be writing down what we ourselves had previously predicted he would write down. In one of Karl Popper's essays, On Clouds and Clocks, he argues that, when two human beings meet eye-to-eye, the question is (so to say) who will fire first. Who is to say? How can we tell? We just have to wait for the outcome.

To return to David Hume's Treatise of Human Nature: in the first two books he asks, "Oh, so all we have is sensory inputs and Euclidean deductions? Where does this get us?" The answer is that it gets us nowhere. As a result, misguided teachers of philosophy label the conclusion that we do not, strictly speaking, know anything, "Humeanism." This of course makes the World unintelligible. But in Book III of the treatise he insists that we can make sense of the World only if we bring certain general ideas of causality, morality, probability and the like to bear on our understanding of things. Without them, nothing will make sense to us. (Notice that this makes Hume's position much closer to Kant's than Kant himself supposed.)

Some years ago, I used to go to Rockefeller University in New York and sit in the bar in the late afternoon, and listen to the conversations of the distinguished scientists there. What sticks in my mind is that they rarely came in and reported that they had just discovered the truth or falsity of particular propositions. Rather, they would say something like, "You know, something happened today that I just cannot make sense of. It just does not fit in." That is how science progresses, by finding ways of fitting together in a consistent manner ideas and theories that previously seemed incompatible. When I was last in touch with physics -incidentally, my first degree was in mathematics and physics - there were a whole lot of phenomena that could be explained on the 


\section{Stephen Toulmin}

assumption that the electron had zero radius and zero mass, and another lot of phenomena that could be explained only on the assumption that it had positive size and positive mass; but there was as yet no consistent framework that explained both sets of phenomena. No doubt this problem has by now been overcome or circumvented so that physicists no longer lose any sleep about it.

Two concluding comments. When I went to Wittgenstein's classes in Cambridge, just after the Second World War, he seemed to us to be a purely original genius, and the passage at the end of the Tractatus about the skeptic who climbs a ladder that he then kicks away seemed to us to have come down from Heaven. In fact, it comes from Sextus Empiricus. The final paragraphs of Sextus's Adversus Mathematicos are the source from which it comes; but Wittgenstein himself was never one to give page references or indeed make any acknowledgements.

Where did he get these ideas from? The answer is now fairly clear. Wittgenstein himself did not go to a public high school. He was taught at home by philosophy graduate students from the school of Fritz Mauthner, who had written a Sprachkritik about which Wittgenstein said, "Alles Philosophie is Sprachkritik, aber nicht in Sinn Mauthners." (All philosophy is critique of language, but not in Mauthner's sense.) Wittgenstein's father was a steel magnate, and a leading member of the local Prodestent community. I might digress here about the parties in the Wittgenstein palace in the Argentinastrasse at which Mahler and Bruno Walter would meet, and about Mahler's three-week psychoanalysis with Freud.

Finally, much of the success of The Uses of Argument, is due to the fact that I deliberately used everyday, colloquial language: grounds, warrants, backing and so on. These are far from being philosophical technicalities, and any reader will recognize their general meaning. The same was in fact true of Aristotle. The Greek names that he gives to the Four Causes are all everyday Classical Greek words: they are the "from what," the "who did it," the "what sort it is," and the "in aid of what." These no more needed explaining to people in his time than our own words about argumentation need explaining today.

Accordingly, I look forward with great pleasure to the constructive and creative discussion of all these issues, beginning with Michael Scriven, and going on from there. What is there left for us to do under the heading of "philosophy" and how is it related to your own work analyzing "argumentation"? Are these purely distinct, or do they rather blend into one another at the margin? That is our central question in this conference, and I look forward to hearing what you all have to say about it.

Stephen Toulmin

Department of Anthropology University of Southern California Los Angeles, CA 90089 